\title{
SAUDAÇÃO PROFERIDA \\ PELO PROFESSOR TÉRCIO SAMPAIO FERRAZ JÚNIOR AO NOVO TITULAR, PROFESSOR VICENTE GRECO FILHO
}

\author{
Excelentíssimo Senhor Diretor, \\ Senhores Professores, \\ Minhas senhoras, meus senhores,
}

Quando conheci Vicente Greco Filho certamente nem ele nem eu podíamos imaginar que estaríamos os dois, frente a frente, numa cerimônia de saudação, em nossa Congregação, de um novo Professor Titular da Faculdade de Direito da USP.

Éramos jovens, adolescentes, românticos talvez, preocupados com as letras, a poesia, a música. Certamente nem um nem outro podia adivinhar, naquela época, o profissional do direito, o educador, nem muito menos os lances atrevidos da vida que nos atirou em tão diversas situações.

Vicente Greco Filho, por sua formação, não é um homem voltado para uma técnica singularizada. Ao contrário, no campo jurídico seus interesses se abriram desde cedo para múltiplas direções. Se o processo, civil e penal, foi desde logo uma paixão, nem por isso o saber técnico deixou de ser alcançado num espectro que cobria a filosofia jurídica, o direito administrativo, o direito penal onde foi, afinal, culminar seu interesse maior.

Vicente Greco Filho, por isso, não é um didata ou um técnico de um saber especializado e irrefletido. Quem se preocupou, já nas suas primeiras publicações, com a prevenção e a repressão relativa a tóxicos, e isto em 1973, quem oito anos depois era capaz de iniciar a publicação de seus três volumes de Direito Processual Civil Brasileiro, quem em 1977 estava atento aos "Direitos Individuais e o Processo Judicial" e em 1989 repicava com a "Tutela Constitucional das Liberdades" não podia ser, como nunca foi, um docente fechado e repetitivo, mas um homem capaz de lecionar o processo, o direito penal, a filosofia do direito, o direito administrativo.

Vicente Greco Filho é, por tudo isto, um jurista. Para quem não o conheça pessoalmente, porém, a figura parece condensar-se na palavra escrita, lavrada no silêncio do pensamento e recolhida nos textos que publicou. 
Referir-me a seus textos, porém, não significa a intenção de reduzi-lo àquilo que escreveu, como se ali fosse possível reificar a sua essência. Na verdade, quando essa essência aparece abjetivamente, sob a forma de um texto escrito, no fundo ela manifesta a identidade da pessoa e, portanto, serve para identificar a autoria. Mas emudece e nos escapa, quando tentamos interpretá-la como o espelho da pessoa viva. A suposição de que a identidade de uma pessoa transcende, em grandeza e importância, tudo o que ela possa fazer ou produzir, é elemento indispensável da dignidade humana (H. Arendt). Só o espírito vulgar consente em atribuir a dignidade de um homem àquilo que ele fez e produziu. Pois o que salva o talento verdadeiramente grande é sua capacidade de arcar com o ônus de sua própria obra, permanecendo superior ao que ele fez. A fonte viva de sua criatividade emana de quem ele é, sendo exterior ao processo de trabalho e independente do que possa ter realizado.

Vicente Greco Filho neste sentido é um homem plural. Sua atividade no Ministério Público, na Administração Pública, na direção de importantes entidades em vários e diferentes governos, sua colaboração em comissões elaboradoras de projetos de lei na sua área de especialização, fazem dele muito mais do que um autor de livros, fazem dele um homem presente nos desafios de sua época.

Mas acima de tudo, Vicente Greco Filho, no trato do direito, quer nos livros, quer na sala de aula, quer na atividade administrativa, quer no tribunal, é um homem que certamente nunca perdeu o senso da arte que soube cultivar como adolescente e que o acompanha até hoje, na música, na pintura, na poesia. Não é um hobby, um passatempo. Mas algo que pessoas como ele sentem em cada ato e cada pensamento.

Por isso ele sabe que nesta Faculdade de Direito do Largo de São Francisco, a fonte imediata do direito sempre foi percebida na capacidade humana de julgar. E que não se trata de um ato frio e neutro, mas de uma capacidade que se relaciona com o sentimento de injustiça, que transforma a sua dor muda e inarticulada em algo comunicativo, voltado para os outros. Nesta Faculdade, todos sabemos que quem julga transfere para o mundo algo muito intenso e veemente que estava aprisionado no seu ser. Não se trata de mera transformação. É mais. Muito mais. É uma transfiguração, verdadeira metamorfose, algo parecido com o que diz Rilke da obra de arte: o curso da natureza requer que tudo queime até virar cinzas, 
mas na arte é como se isto fosse invertido, de modo que até as cinzas pudessem irromper em chamas. Talvez por isso também, os juristas romanos tivessem visto no direito uma arte, ars boni et aequi. O processo de julgar, em si, não é capaz de produzir e fabricar coisas tangíveis como sentenças, votos, opiniões, da mesma forma que o espírito artístico, por si, não é capaz de produzir e fabricar coisas tangíveis como livros, pinturas, esculturas, partituras musicais. Mas nesta Faculdade, todos sabemos que o direito, como a arte, exige uma transformação reificada no mundo. Pois sem essa materialização, nem o julgamento nem o espírito artístico podem tornar-se coisas tangiveis. Por isso, o preço do direito como o preço da arte é a própria vida: é na letra morta que o espirito vivo deve sobreviver. Deste amortecimento ambos só escapam quando a letra morta entra novamente em contato com uma vida disposta a ressuscitá-la, ainda que esta ressurreição, como todas as coisas vivas, tenha de morrer também. Por isso, nesta Faculdade do Largo de São Francisco, qualquer um sabe que o direito, como a arte, são fenômenos de comunicação, não existem no isolamento solipsista, exigindo do autor e do fruidor a mesma disponibilidade vital: liberdade.

Vicente Greco Filho, promotor, administrador, homem de letras jurídicas, professor, é acima de tudo um amante da liberdade. E não apenas pelos textos que sobre ela escreveu, mas porque a inscreveu na sua ocupação diária com o mundo da convivência.

A Faculdade de Direito da USP não é apenas uma casa de ensino e aprendizado do direito. É também uma confraria de cultura. A cultura, como o humanismo, exige esta capacidade de mediar, avaliar e escolher entre qualidades que se opõem umas às outras de um sem-número de modos. Ao adentrar no colégio de seus mestres, Vicente os encontra como técnicos do direito e como homens de cultura, humanistas, capazes de elevarem-se acima dos conflitos do mundo jurídicosocial, da mesma maneira como se elevam em liberdade acima das especialidades que aprenderam e exercem. Vicente Greco Filho sempre soube escolher sua companhia entre homens, entre coisas e entre pensamentos, tanto no presente como no passado. Para ele a cultura não é refinamento social nem o humanismo um status correspondente, mas aquela atitude de carinhoso cuidado com as coisas do mundo. E pelo privilégio de tê-lo entre nós, como Professor Titular, eu o saúdo em nome de todos. 